\title{
SHORT-TERM EFFECTS OF A PRESCRIBED BURN ON SONGBIRDS AND VEGETATION IN MOUNTAIN BIG SAGEBRUSH
}

\author{
Aaron L. Holmes ${ }^{1,2}$
}

\begin{abstract}
I measured songbird abundance and vegetation cover in and around a 420-ha prescribed burn in a mountain big sagebrush community located at $2133 \mathrm{~m}$ elevation. Data were collected during the 3rd growing season after the fire. Brewer's Sparrow and Sage Thrasher occurred in lower abundance on sites that were largely or completely burned relative to sites that were outside the fire perimeter or within unburned islands of shrubs. The number of Brewer's Sparrow detections was linearly related to remaining sagebrush cover. In contrast, Horned Lark occurred at higher abundances on sites where shrub cover had been removed in the prescribed burn. Cover of perennial grasses and cover of 4 of the 5 most common forbs was greater on burned sites than on unburned sites.
\end{abstract}

Key words: prescribed fire, sagebrush, Artemisia tridentata, Oreoscoptes montanus, Eremophila alpestris, Spizella breweri.

In recent decades increased effort has been devoted to understanding deviations from natural fire regimes in the sagebrush biome (Whisenant 1990, Miller and Tausch 2001, Miller et al. 2005). Concerns over transitions to exotic annual grasslands (facilitated by more frequent fires; Allen-Diaz and Bartolome 1998, West 2000) or transitions to pinyon-juniper woodlands (facilitated by a reduction in fire frequency; Young and Evans 1981, Miller and Wigand 1994, Miller and Rose 1999, Miller et al. 2005) have understandably dominated discussions. Little consideration has been given to the fire ecology of mountain big sagebrush (Artemisia tridentata vaseyana) habitats that are at low risk of both annual grass invasion and conifer encroachment. The expected change in habitat structure resulting from the synergistic effects of fire suppression and grazing pressures is an increase in sagebrush cover and a reduction in perennial grasses and forbs (Miller et al. 2000).

In the absence of a disturbance event or woodland encroachment, sagebrush will typically continue to dominate, with new individuals replacing those that senesce. Because of this accumulation of shrubs, mountain big sagebrush stands in this condition contain greater fuel loadings and a higher ratio of dead fuel to live fuel than stands that have burned in recent decades. Thus, when a wildfire does occur, the increased woody-fuel loadings increase fire residency and downward transfer of heat with potentially deleterious effects on underground tissues of remaining perennial grasses, soil organisms, and soil nutrients (DeBano et al. 1998). Further, a continuous shrub layer with a high ratio of dead fuel to live fuel can facilitate a higher-intensity fire and result in a more complete burn. Patchy burns provide potential seed sources for postfire sagebrush recovery as well as post-fire refugia for wildlife dependent upon shrub structure. Prescribed burns, which can be executed outside of the normal fire season when temperatures are lower and soil moisture is greater, provide an opportunity to mitigate potential negative outcomes from a highintensity fire in these altered landscapes.

Our understanding of the responses of birds and other wildlife populations to fire and postfire habitat changes remains simplistic given the complex nature of fire in landscapes dominated by sagebrush species. A recent review paper on the role of fire in shaping bird communities in sagebrush habitats (Knick et al. 2005) reveals a surprisingly small amount of research on the subject, especially for songbirds. In a review of research needs for the conservation of neotropical migrant landbirds (Donovan et al. 2002), the number 1 research priority in the West included understanding

${ }^{1}$ PRBO Conservation Science, 4990 Shoreline Hwy., Stinson Beach, CA 94970. E-mail: aholmes@prbo.org

${ }^{2}$ Oak Creek Lab of Biology, Department of Fisheries and Wildlife, Oregon State University, Corvallis, OR. 
the relationships between shrubsteppe bird species and the landscape patterns and habitat structures that result from altered fire regimes.

I present results from a study designed to characterize songbird and vegetation communities during the 3rd growing season following a prescribed burn in a high-elevation mountain big sagebrush community. Based on published studies pertaining to habitat associations and responses to fire, I predicted that sites with greater amounts of shrub cover within the post-fire landscape would support greater numbers of sagebrush-obligate species (Knick and Rotenberry 1999, Reynolds et al. 1999, Rotenberry et al. 1999, Welch 2002). I also predicted that sites where the majority of the sampling plot was burned would support greater numbers of ground-nesting species (Castrale 1982, Petersen and Best 1987, Kerley and Anderson 1995, Reinkensmeyer 2000, Welch 2002). Several important limitations of this study need to be acknowledged. First, results are based on a single season of data collection and provide only a snapshot of songbird responses, which may vary temporally in the years and decades following a fire. Second, this study considers only a single burn. Although the burn was well sampled through systematic sampling, inferences about other locations must be made with caution. Despite these limitations, results presented herein add to the small but growing body of published information on habitat use by songbirds following fire in the sagebrush biome. These results should help inform the decision-making process of where and how to execute prescribed burns in mountain big sagebrush.

\section{Methods}

Data were collected on Oregon Canyon Mountain, Vale County, Oregon $\left(118^{\circ} 4^{\prime} 38^{\prime \prime} \mathrm{W}\right.$, $\left.42^{\circ} 7^{\prime} 30^{\prime \prime} \mathrm{N}\right)$ during June 2004 . The study area was at 2133 m elevation, contained gently rolling topography, and encompassed the majority of an area treated with a prescribed burn in October 2001. The outer perimeter of the burned area was mapped with GPS instrumentation and amounted to 420 ha. The actual burned area within this perimeter was estimated to be between 283 ha and 324 ha. The burn was spatially complex, with multiple and varied unburned islands retained within the perimeter, and burned fingers extending out into adjacent sagebrush.

The shrub community was dominated by mountain big sagebrush but also contained scattered snowberry (Symphoricarpos oreophilus) and bitterbrush (Purshia tridentata). At least 5 species of perennial grasses occurred on the site but they were not identified to species. Cheatgrass was limited to several very small patches $\left(<1 \mathrm{~m}^{2}\right)$ within the sampling area and was noted only in portions of the area that had burned. Dominant forbs included sagebrush violet (Viola vallicola), lupine (Lupinus sp.), and senecio (Senecio sp.).

To sample bird community and vegetation attributes in the 3rd growing season following the burn, I established a grid of 37 sampling points spaced $300 \mathrm{~m}$ apart. The points represented a continuum of completely burned to completely unburned areas. At each, we conducted 5-minute point-count surveys following standard protocols (Ralph et al. 1993) during which all birds detected were recorded by species. Observers estimated distance to each bird by using a laser rangefinder. Surveys were begun approximately 15 minutes after local sunrise and completed within 2 hours. Each point was surveyed once on 4 June or 5 June, and again on 18 June or 19 June 2004. A total of 4 observers conducted the counts. All observers had at least 1 previous season of experience with the survey protocol in sagebrush habitats and were assigned to different survey points on the different visits to reduce potential observer bias.

Vegetation structure was sampled using several methods. Shrub cover and height were measured using two 50-m line intercept transects (Canfield 1941) at each point. A coin toss determined whether these transects were oriented on a north-south axis or an east-west axis, and transects began $15 \mathrm{~m}$ from the sampling point. Thus, at each point the 2 transects were separated by $30 \mathrm{~m}$. Ground cover variables-grass cover, forb cover, litter, rock and bare ground-were estimated within $0.2 \times$ 0.5-m herbaceous sampling plots spaced every $5 \mathrm{~m}$ along the same transects (Daubenmire 1959). The cover of each dominant forb species was estimated separately, and less common species were combined into a single cover estimate. Ground cover variables were compared between the sampling frames that fell 
TABLE 1. Mean bird abundance and diversity indices for sites with $\leq 35 \%$ of the sampling area burned $(n=21)$ and those with $\geq 70 \%$ burned $(n=16)$.

\begin{tabular}{|c|c|c|c|c|c|c|}
\hline \multirow[b]{2}{*}{ Index } & \multicolumn{2}{|c|}{$\leq 35 \%$ burned } & \multicolumn{2}{|c|}{$\geq 70 \%$ burned } & \multicolumn{2}{|c|}{ Rank-sum test } \\
\hline & $\bar{x}$ & $s$ & $\bar{x}$ & $s$ & $Z$ & $P$ \\
\hline Brewer's Sparrow & 6.00 & 1.92 & 2.75 & 2.14 & 3.776 & 0.0002 \\
\hline Sage Thrasher & 1.24 & 1.00 & 0.44 & 0.81 & 2.731 & 0.0063 \\
\hline Vesper Sparrow & 1.38 & 1.24 & 2.19 & 1.56 & -1.675 & 0.0939 \\
\hline Horned Lark & 0.05 & 0.22 & 1.25 & 1.61 & -3.203 & 0.0014 \\
\hline Species diversity & 2.43 & 0.69 & 2.61 & 0.83 & -0.706 & 0.48 \\
\hline Species richness & 3.10 & 0.83 & 2.88 & 0.89 & 1.112 & 0.26 \\
\hline Proportion burned & 0.08 & 0.13 & 0.90 & 0.11 & - & - \\
\hline
\end{tabular}

on a burned site and those that fell outside the perimeter or within unburned islands. I generated a "proportion burned" index based on the number of the 20 sampling frames at each point that occurred within the burn. In addition, prior to vegetation sampling, observers made a simple ocular estimate of the proportion of the area within $100 \mathrm{~m}$ that had burned. These 2 indices were very tightly correlated $(r=0.95)$ so in analyses, I used only the one derived from the systematic sampling.

I generated an index to bird abundance using the total number of individuals detected within $100 \mathrm{~m}$ during both visits (Nur et al. 1999). Species diversity was measured using a transformation of the Shannon-Weiner index (Krebs 1989), and species richness was indexed as the number of bird species detected within $100 \mathrm{~m}$ over both surveys at a given point.

I tested predictions regarding patterns of bird abundance in relation to fire-mediated shrub cover by comparing bird indices between sites with a high $(>50 \%)$ versus low $(<50 \%)$ proportion of the sampled area burned using a Wilcoxon rank-sum test. Habitat measurements of interest were likewise compared. Simple linear regression was used to describe the relationships between bird abundances and post-fire shrub cover on a point-by-point basis and to relate shrub cover to the proportion of a sampling area that was burned in 2001.

\section{RESUlTS}

Ten species of birds were detected in the surveys: Greater Sage-Grouse (Centrocercus urophasianus), Brewer's Blackbird (Euphagus cyanocephalus), Horned Lark (Eremophila alpestris), Rock Wren (Salpinctes obsoletus), Say's Phoebe (Sayornis saya), Sage Thrasher (Oreoscoptus montanus), Vesper Sparrow (Pooe- cetes gramineus), Brewer's Sparrow (Spizella breweri), Green-tailed Towhee (Pipilo chlorurus), and Western Meadowlark (Sturnella neglecta).

Big sagebrush cover was highly variable among sampling points, ranging from $0 \%$ to $49.5 \%(\bar{x}=19.99, s=16.84)$, and was largely dependent on the spatial complexity of the burn at that scale. As expected, shrub cover declined as the proportion of the sampling area that had burned increased. A linear regression between the square root of big sagebrush cover and the proportion burned demonstrates a close relationship $\left(n=37, F_{1,35}=225.8, P\right.$ $\left.<0.0001, r^{2}=0.87\right)$.

I grouped sampling locations into sites with either $>50 \%$ or $<50 \%$ of the sampling area burned. All sites, however, were either $\leq 35 \%$ or $\geq 70 \%$ burned, so those groupings are used hereafter. The points with greater shrub loss supported fewer Brewer's Sparrow and Sage Thrasher and greater numbers of Horned Lark (Table 1). Vesper Sparrows tended to occur in greater numbers on the burned areas as well, but the rank-sum test was inconclusive by conventional standards of statistical significance. Other species were detected at fewer than 4 sampling points and were not analyzed. Although estimates are imprecise due to small sample sizes, I also calculated the relative differences in abundance indices for points that were completely outside the prescribed burn $(n=14)$ and for points where the burn impacted $\leq 35 \%$ of the count area (mean percentage burned $=24 \%, n=7$ ). Brewer's Sparrow abundance was $7 \%$ lower on sites that were lightly burned relative to unburned sites, although this difference was not statistically significant (95\% C.I. spans a 38\% decrease to a $24 \%$ increase). In contrast, at sites where $>70 \%$ of the canopy was removed, Brewer's Sparrow 


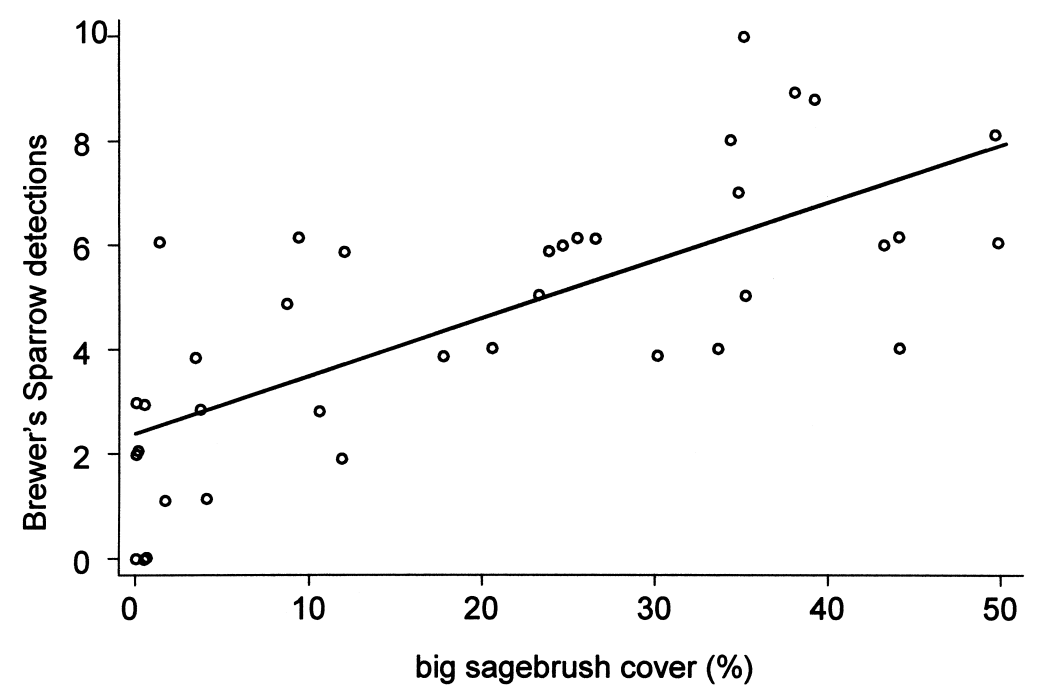

Fig. 1. Brewer's Sparrow abundance, as indexed by the number of detections within $100 \mathrm{~m}$ summed across 2 surveys, in relation to post-fire mountain big sagebrush $\operatorname{cover}\left(n=37, F_{1,35}=38.19, P<0.0001, r^{2}=0.52\right)$.

was $55 \%$ lower in abundance $\left(95 \%\right.$ C.I.: $\mathrm{L}_{1}=$ $\left.-79 \%, \mathrm{~L}_{2}=-31 \%\right)$. Sage Thrasher abundance was also not distinguishable between the unburned sites and the small sample of points where $\leq 35 \%$ of the area burned. The estimated difference was $-26 \%$, but again, the confidence interval included 0 and ranged from $-98 \%$ to $+45 \%$. However, at sites with $>70 \%$ of the area burned, Sage Thrasher abundance was reduced by $68 \%\left(95 \%\right.$ C.I.: $\mathrm{L}_{1}=-100 \%, \mathrm{~L}_{2}=$ $-24 \%)$ relative to the unburned points.

Fifty-two percent of the variation in Brewer's Sparrow detections was explained by remaining sagebrush cover as measured at individual sampling locations (Brewer's Sparrow $=2.39$ $+0.1104 *$ sagebrush cover; Fig. 1). Variation at the sampling-point scale in the abundances of the other species was explained to lesser degrees. Approximately $20 \%$ of variation in Sage Thrasher abundance (sqrt[Sage Thrasher] $=0.3502+0.1714 *$ sagebrush cover; $F_{1,35}$ $=8.57, P=0.006), 28 \%$ of the variation in Horned Lark abundance (sqrt[Horned Lark] $=0.7812-0.0213 *$ sagebrush cover; $F_{1,35}=$ $13.85, P=0.0007)$, and $11 \%$ of the variation in Vesper Sparrow (sqrt[Vesper Sparrow] $=0.4011$ $-0.0133 *$ sagebrush cover; $F_{1,35}=4.35, P=$ $0.04)$ can be accounted for by sagebrush cover.

Areas that had burned in 2001 supported greater cover of perennial grasses, lupine, senecio, and phlox, but less cover of sagebrush violet. Bluebell (Mertensia longiflora) cover was similar between burned and unburned plots (Table 2). In general, the species composition of the forb and grass community was similar in burned and unburned areas, suggesting that species which increased on burned areas were present prior to the burn and were undergoing a post-fire release.

\section{Discussion}

Short term responses of songbirds to fire in this study were consistent with my predictions and with responses reported previously in the literature for other locations (reviewed in Knick et al. 2005). Sage Thrasher has been reported to have variable responses to fire: no measurable response (Castrale 1982), a small positive response that was significant only 4 years postfire (Petersen and Best 1999), and negative responses (Welch 2002, McIntyre 2002). Reported responses for Brewer's Sparrow are consistently negative (Castrale 1982, Bock and Bock 1987, Knick and Rotenberry 1999, Petersen and Best 1999, Reinkensmeyer 2000, McIntyre 2002, Welch 2002). Reported responses for the ground-nesting species, Horned Lark and Vesper Sparrow, have been either positive or neutral in roughly equal proportions (Castrale 1982, Petersen and Best 1987, Kerley and Anderson 1995, Reinkensmeyer 2000, McIntyre 2002, Welch 2002). Previous researchers 
TABLE 2. Cover of herbaceous vegetation estimated from sampling frames that fell within the prescribed burn $(n=$ $320)$ and those outside of the burn perimeter $(n=420)$.

\begin{tabular}{|c|c|c|c|c|c|c|}
\hline \multirow[b]{2}{*}{ Variable } & \multicolumn{2}{|c|}{ Not burned } & \multicolumn{2}{|c|}{ Burned } & \multicolumn{2}{|c|}{ Rank-sum test } \\
\hline & $\bar{x}$ & $s$ & $\bar{x}$ & $s$ & Z & $P$ \\
\hline Perennial grass $(\%)$ & 6.43 & 11.40 & 10.25 & 11.76 & -5.179 & $<0.0001$ \\
\hline Lupinus sp. $(\%)$ & 4.58 & 9.44 & 14.93 & 16.50 & -11.115 & $<0.0001$ \\
\hline Senecio sp. $(\%)$ & 0.42 & 1.76 & 2.08 & 4.05 & -9.186 & $<0.0001$ \\
\hline Viola vallicola $(\%)$ & 8.42 & 10.61 & 6.76 & 9.88 & 2.622 & 0.0087 \\
\hline Phlox spp. (\%) & 0.22 & 1.40 & 1.21 & 3.00 & -7.699 & $<0.0001$ \\
\hline M. longiflora $(\%)$ & 0.07 & 0.65 & 0.13 & 0.87 & -1.558 & 0.1192 \\
\hline Litter & 25.28 & 25.72 & 6.40 & 12.44 & 12.996 & $<0.0001$ \\
\hline
\end{tabular}

have suggested that numbers of sagebrushobligate songbirds were not greatly reduced over the short term with partial removal $(<50 \%)$ of sagebrush (Best 1972, Petersen and Best 1987, Petersen and Best 1999). In this study, removal of $5 \%-35 \%$ of the shrub layer at a local scale resulted in an estimated 7\% reduction in Brewer's Sparrow detections and a $26 \%$ reduction in Sage Thrasher detections, although neither of these estimated differences were statistically significant. Both of these species used the burned area for nesting and foraging. Multiple nests of Brewer's Sparrow and a single nest of Sage Thrasher were located in islands of sagebrush within the prescribed burn area, demonstrating that even small unburned patches can provide nesting habitat for both of these species. One Sage Thrasher nest was located in a patch of shrubs that was only $10 \mathrm{~m}$ long and 3-4 $\mathrm{m}$ wide. The adults associated with this nest were observed foraging in the surrounding burned habitat.

Burned areas had higher cover of several species of forbs-a desirable habitat feature for nesting and brood-rearing sage grouse (Wamboldt et al. 2002). Forb production following fire events is inconsistent, with increases occurring after some (Harniss and Murray 1973, Pyle and Crawford 1996), but not all fire events (Fischer et al. 1996, Nelle et al. 2000). The most important factor in determining post-fire forb response is likely preburn site condition. In this case, species composition and frequency of occurrence for dominant forbs in unburned areas were similar to the burned areas, suggesting that the response was a function of release rather than colonization. Wrobleski and Kauffman (2003) found that burning in Wyoming big sagebrush caused morphological changes such as significantly greater numbers of racemes, flowers, and flower heads in key species of forbs, as well as phenological changes such as earlier flowering and increased length of flowering season. Although I did not quantify these characteristics, I did observe that both lupine and senecio on the burn tended to be larger and have more flowers than on adjacent sagebrush areas. Precipitation patterns may also be important in determining post-fire responses in forb species.

Increased patchiness of burns and associated islands of unburned patches provide breeding habitat for shrub-dependent bird species, but may also provide habitat for dispersing species and cover for escape from predators, and may serve to increase recovery of plants by providing seed sources and harboring animals that facilitate seed dispersal (Longland and Bateman 2002). The value of these habitat islands to breeding birds may be dependent on their proximity to more continuous areas of shrub cover. Additional work is necessary to evaluate this relationship and to determine whether reproductive success varies between nests in unburned islands versus those placed in continuous sagebrush canopies. Results from this study suggest that increases in ground-nesting species can be achieved through prescribed burning, a result that is not novel or unexpected. The degree to which shrub-nesting species are negatively impacted is related, at least in part, to the amount of canopy removal. Thus, local declines in sagebrush obligates from prescribed burns can be mitigated, at least in part, by canopy retention.

\section{ACKNOWLEDGMENTS}

I thank J. Sadowski for providing support and local knowledge of the study area. I am grateful to C. Baum, A. Hannuksela, and C. Martz for their help with data collection and 
to A. Hannuksela and D. Barton for assistance with data entry. Financial support was provided under a cost-share agreement between the Bureau of Land Management, Oregon State Office and PRBO Conservation Science. This is PRBO contribution \# 1333.

\section{Literature Cited}

Allen-Diaz, B., AND J.W. Bartolome. 1998. Sagebrushgrass vegetation dynamics: comparing classical and state-transition models. Ecological Applications 8: 795-804

BEST, L.B. 1972. First year effects of sagebrush control on two sparrows. Journal of Wildlife Management 36: $534-544$.

Bock, C.E., AND J.H. Bock. 1987. Avian habitat occupancy following fire in a Montana shrubsteppe. Prairie Naturalist 19:153-158.

Canfield, R.H. 1941. Application of the line interception method in sampling range vegetation. Journal of Forestry 39:388-394.

Castrale, J.J. 1982. Effect of two sagebrush control methods on nongame birds. Journal of Wildlife Management 46:945-952.

DaubenmiRe, R. 1959. A canopy-coverage method of vegetational analysis. Northwest Science 33:43-63.

DeBano, L.F., D.G. Neary, and P.F. Ffolliott. 1998. Fire's effects on ecosystems. John Wiley \& Sons, Inc., New York.

Donovan, T.E., C.J. Beardmore, D.N. Bonter, J.D. Brawn, R.J. CoOper, J.A. Fitzgerald, F. RofD, et AL. 2002. Priority research needs for the conservation of neotropical migrant landbirds. Journal of Field Ornithology 73:329-339.

Fischer, R.A., K.P. Reese, And J.W. Connelly. 1996. An investigation on fire effects within xeric sage grouse brood habitat. Journal of Range Management 49:194-198.

Harniss, R.O., and R.B. Murray. 1973. Thirty years of vegetal change following burning of sagebrush-grass range. Journal of Range Management 26:322-325.

Kerley, L.L. And S.H. Anderson. 1995. Songbird responses to sagebrush removal in a high elevation sagebrush steppe ecosystem. Prairie Naturalist 27:129146.

Knick, S.T., A.L. Holmes, and R. Miller. 2005. The role of fire in structuring sagebrush habitats and bird communities. Studies in Avian Biology 30.

KNick, S.T., AND J.T. Rotenberry. 1999. Spatial distribution of breeding passerine bird habitats in southwestern Idaho. Studies in Avian Biology 19:104-111.

Krebs, C.J. 1989. Ecological methodology. Harper and Row Publishers, New York.

LONGLAND, W.S., AND S.L. BATEMAN. 2002. Viewpoint: the ecological value of shrub islands on disturbed sagebrush rangelands. Journal of Range Management 55: 571-575.

McIntyre, K.K. 2002. Species composition and beta diversity of avian communities in burned, mixed, and unburned sagebrush steppe habitat at Sheldon National Wildlife Refuge, Nevada. Master's thesis, Sul Ross University, Alpine, TX.

Miller, R.F., J.D. Bates, T.J. Svejcar, F.B. Pierson, and L.E. Eddleman. 2005. Biology, ecology, and man- agement of western juniper. Technical Bulletin 152 Oregon State University Agricultural Research Station.

MilleR, R.F., AND J.A. Rose. 1999. Fire history and western juniper encroachment in sagebrush steppe. Journal of Range Management 52:550-559.

Miller, R.F., T.J. Svejcar, And J.A. Rose. 2000. Impacts of western juniper on plant community composition and structure. Journal of Range Management 53: $574-585$.

Miller, R.F., and R.J. Tausch. 2001. The role of fire in pinyon and juniper woodlands: a descriptive analysis. Pages 15-30 in K.E.M. Galley and T.P. Wilson, editors, Proceedings of the Invasive Species Workshop: the role of fire in the control and spread of invasive species. Miscellaneous Publication No. 11, Tall Timbers Research Station, Tallahassee, FL.

Miller, R.F., and P.F. Wigand. 1994. Holocene changes in semiarid pinyon-juniper woodlands. BioScience 44:465-474.

Nelle, P.J., K.P. Reese, AND J.W. Connelly. 2000. Longterm effects of fire on sage grouse habitat. Journal of Range Management 53:586-591.

Nur, N., S.L. JonES, AND G.R. GEupEL. 1999. A statistical guide to data analysis of avian monitoring programs. U.S. Department of the Interior, Fish and Wildlife Service, BTP-R6001-1999, Washington, DC.

Petersen, K.L., And L.B. Best. 1987. Effects of prescribed burning on nongame birds in a sagebrush community. Wildlife Society Bulletin 15:317-329.

. 1999. Design and duration of perturbation experiments: implications for data interpretation. Studies in Avian Biology 19:230-236.

Pyle, W.H., AND J.A. CRAWFORD. 1996. Availability of foods of sage grouse chicks following prescribed fire in sagebrush-bitterbrush. Journal of Range Management 49:320-324.

Ralph, C.J., G.R. Geupel, P. Pyle, T.E. Martin, and D.F. DESANTE. 1993. Field methods for monitoring landbirds. USDA Forest Service Publication, PSW-GTR 144, Albany, CA.

ReinkensmeyeR, D.P. 2000. Habitat associations of bird communities in shrub-steppe and western juniper woodlands. Master's thesis, Oregon State University, Corvallis.

Reynolds, T.D., T.D. Rich, and D.A. Stephens. 1999. Sage Thrasher (Oreoscoptes montanus). In: A. Poole and F. Gill, editors, The birds of North America, no. 463. The Birds of North America, Inc., Philadelphia, PA.

Rotenberky, J.T., M.A. Patten, and K.L. Preston. 1999. Brewer's Sparrow (Spizella breweri). In: A. Poole and F. Gill, editors, The birds of North America, no. 390. The Birds of North America, Inc., Philadelphia, PA.

Wambolt, C.L., A.J. Harp, B.L. Welch, N. Shaw, J.W. Conelly, K.P. Reese, C.E. Braun, et aL. 2002. Conservation of Greater Sage-Grouse on public lands in the western U.S.: implications of recovery and management policies. Policy Analysis Center for Western Public Lands, PACWPL Policy Paper SG-02-02.

WELCH, B.L. 2002. Bird counts in stands of big sagebrush and greasewood Research Note RMRS-RN-16, U.S. Department of Agriculture, Forest Service, Rocky Mountain Research Station, Ogden, UT. 8 pp.

WEST, N.E. 2000. Synecology and disturbance regimes of sagebrush steppe ecosystems. Pages 15-26 in P.G. Entwistle, A.M. DeBolt, J.H. Kaltenecker, and K. Steenhof, compilers, Proceedings: sagebrush steppe 
ecosystems symposium. Bureau of Land Management Publication No. BLM/ID/PT-001001+1150, Boise, ID.

Whisenant, S.G. 1990. Changing fire frequencies on Idaho's Snake River Plains: ecological and management implications. Pages 4-10 in E.D. McArthur, E.M. Romney, S.D. Smith, and P.T. Tueller, editors, Proceedings - symposium on cheatgrass invasion, shrub die-off, and other aspects of shrub biology and management. USDA Forest Service, Intermountain Research Station, Ogden, UT.
Wrobleski, D.W., AND J.B. KaUfFman. 2003. Initial effects of prescribed fire on morphology, abundance, and phenology of forbs in big sagebrush communities in southeastern Oregon. Restoration Ecology 11:82-90.

Young, J.A., AND R.A. Evans. 1981. Demography and fire history of a western juniper stand. Journal of Range Management 34:501-506.

Received 1 June 2005 Accepted 22 August 2006 